\title{
Sen's capability approach and Post Keynesianism: similarities, distinctions, and the Cambridge tradition
}

\begin{abstract}
The capability approach to human development, proposed by Amartya Sen and others, is now a prominent perspective within welfare economics and development economics. I argue that the capability approach, like Post Keynesianism, can be situated within the Cambridge economic tradition, a tradition grounded on classical economics, and characterized by an ontological focus on themes such as openness and uncertainty, and by a common social philosophy. Furthermore, I argue that the capability approach and Post Keynesianism can be seen as complementary and mutually enriching approaches.
\end{abstract}

Key words: Cambridge tradition, capability approach, methodology, ontology, Post Keynesianism.

Amartya Sen's capability approach is, at a general level, part of an older tradition within practical reasoning (of which welfare economics and the study of human behavior are particular branches) that, as Sen (1999, p. 289) argues, goes back to Aristotle. However, whereas Sen's general contribution (especially his analysis of well-being) is strongly influenced by an Aristotelian account of human functioning, Sen's study of economic behavior is greatly inspired by Adam Smith. In fact, Putnam (2002) and Walsh $(2000 ; 2003 ; 2008)$ consider this return to Smith as the central aspect of Sen's project. According to Putnam and Walsh, the twentieth century witnessed a revival of classical economic thought in two stages.

The first stage came through Piero Sraffa (1960), who was concerned with bringing back David Ricardo's analytical framework. The second

Nuno Ornelas Martins is an assistant professor of economics at the School of Economics and Management of the Portuguese Catholic University (Porto). For helpful comments on an earlier version of the paper, the author is grateful to Geoff Harcourt, John Latsis, Tony Lawson, and an anonymous referee. The usual disclaimer applies.

Journal of Post Keynesian Economics/Summer 2009, Vol. 31, No. 4691

(C) 2009 M.E. Sharpe, Inc.

$0160-3477 / 2009 \$ 9.50+0.00$.

DOI 10.2753/PKE0160-3477310409 
stage of this revival of classical economic thought underpins Sen's writings, which are much influenced by Smith's conception of the human agent, in which the latter is driven by a complexity of ethical motivations and moral sentiments, and not just by utility optimization as in neoclassical economics.

In this paper, I argue that it is not only in Sen's and Sraffa's contributions that we find a revival of classical economics, but in the whole Cambridge economic tradition, to which Sen and Sraffa belong. The Cambridge tradition is characterized by an ontological focus on themes such as openness and uncertainty, by a common social philosophy, and a return to classical economics, features that contrast with the neoclassical perspective in important ways.

The coherence of projects within the Cambridge tradition such as Post Keynesianism has been much debated by authors such as Arestis (1996), Davidson (2003-4; 2005), Dow (1992; 2005), Hamouda and Harcourt (1988), Harcourt (1981; 2003), Harcourt and Kerr (2003), King (2002; 2005), Lavoie (2005), Lawson (1994; 1999; 2003), Pratten (1999), and Sawyer (1988). Authors such as Backhouse (2006) or Medema (2007), on the other hand, have been preoccupied with the Cambridge "welfare" tradition, which starts with Henry Sidgwick, and has Alfred Marshall and Arthur Pigou as key figures.

The coherence of these two different traditions with each other, and of leading figures such as Marshall, John Maynard Keynes, and Sraffa, was already discussed by authors such as Harcourt (1981; 2003), who devoted much time to the study of the Cambridge economic tradition. In this paper, I intend to extend this discussion to the analysis of Sen's capability approach, which can be taken to be a continuation of the Cambridge "welfare" tradition, which goes from Sidgwick to Sen, and scrutinize its relationship to the other Cambridge tradition - namely, the Keynesian tradition.

Of course, the coherence of the Cambridge tradition is a most controversial topic, as the debate concerning the differences between the Sraffian tradition and other Post Keynesians shows. ${ }^{1}$ In this sense, there would be some advantages in discussing only the relationship between Sen and Post Keynesianism, instead of addressing the topic of the Cambridge tradition here. However, Sraffa is included among the several Cambridge economists that Sen acknowledges as key influences (see Klamer, 1989;

1 See, for example, Davidson (2003-4; 2005), Dequech (2007-8), Dow (2005), Harcourt (1981; 2003), Harcourt and Kerr (2003), King (2002; 2005), Lavoie (2005), Pratten (1999). 
Sen, 2003), so a complete assessment of Sen's contribution, and of its relation to Post Keynesianism, will not be complete without considering Sraffa, and the whole Cambridge atmosphere in which Sen started his academic work.

\section{The Cambridge economic traditions}

One can roughly identify two traditions of economic thought in Cambridge, which can be named as the Cambridge "welfare" tradition (for recent studies of this tradition, see Backhouse, 2006; Medema, 2007) and the Cambridge "Keynesian" tradition (for an overview of which, see Harcourt, 2003; Harcourt and Kerr, 2003; Pasinetti, 2005). The former tradition can be traced back to Sidgwick, and it underpins the work of economists such as Marshall and Pigou.

The authors of the Cambridge "welfare" tradition were mainly concerned with the impact of economics on human well-being. Marshall and Pigou (and also authors such as Dennis Robertson, James Meade, and Tony Atkinson) can be situated in the neoclassical subdivision of the Cambridge "welfare" tradition, to which Keynes, and later Sen, also belonged but quickly abandoned.

The capability approach, and Sen's critique of contemporary neoclassical economics, and of the limited view of economics it provides, can be seen as a continuation of the Cambridge "welfare" tradition, if we take a broader view of such tradition, as a perspective preoccupied with the characterization of human well-being where the latter need not be defined only in terms of utilities, as in neoclassical economics.

Keynes (1936) famously rejected the neoclassical branch of the Cambridge "welfare" tradition in which he had been brought up, and initiated the Cambridge "Keynesian" tradition, which includes, in addition to Keynes, economists such as Richard Kahn, Roy Harrod, Joan Robinson, Austin Robinson, and Nicholas Kaldor. Authors such as Sraffa (and his followers) can be said to constitute a subdivision of their own, because unlike Keynes, they keep Ricardo as their main influence (for different reasons, Michal Kalecki and his followers could also be said to constitute yet another branch of the Cambridge Keynesian tradition). Keynes, on the other hand, argues that the origins of his approach can be traced back to the Cambridge classical economist Thomas Robert Malthus, and the latter's arguments against Ricardo, and against Say's law.

However, Sraffa was very close to the Keynesian circle, in the same way that Sraffian authors remained very close to the other Cambridge Keynesians, for example, during the Cambridge Capital Controversy, 
which opposed economists of Cambridge University such as Robinson, Sraffa, Luigi Pasinetti, or Pierangelo Garegnani, to American economists based in Cambridge, Massachusetts, such as Paul Samuelson or Robert Solow. ${ }^{2}$ Nevertheless, there are important differences between Sraffians and other Post Keynesians, which will be addressed below. Of course, the Cambridge Keynesian tradition went beyond England, and the Post Keynesian tradition is now well established in the United States, too, through the work of authors such as Paul Davidson, Jan Kregel, Hyman Minsky, and Sidney Weintraub, among many others.

\section{The Cambridge tradition and classical economic thought}

Pasinetti (2005) notes that one of the key characteristics of the Cambridge school of Keynesian economics is its inspiration in classical economic thought, in opposition to the marginalists and neoclassical thought. Other prominent economists associated with Cambridge, such as Garegnani $(1984 ; 2002)$, also stress this opposition between classical economics and the marginalists, and place their approach closer to classical economics. This inspiration in classical economic thought, such as the critique of neoclassical theory, constitutes a strong similarity between the Cambridge Keynesian tradition and Sen's contribution.

In fact, the Cambridge "welfare" tradition, too, is closely associated with classical economics. Its authors were sympathetic toward classical economics, too, from Sidgwick (an admirer of John Stuart Mill) to Sen (much influenced by Smith). Even the neoclassical branch of the Cambridge "welfare" tradition is more connected to classical thought than most neoclassical authors, and the dominant neoclassical perspective inspired in Leon Walras. Thus, Marshall, the most prominent author of the neoclassical branch of the Cambridge "welfare" tradition, regards many aspects of classical theory as appropriate for long-run analysis, and considers that the neoclassical perspective went too far in emphasizing the role of utility-driven demand over the (relatively neglected) classical explanation of prices in terms of cost of production.

Bringing classical economic thought back seems thus to be a dominant tone in the Cambridge traditions. Of course, each branch of the Cambridge traditions emphasized different classical authors. Keynes regarded Malthus as an inspiration to his work, and strongly disagreed with Ricardo. But Sraffa, on the other hand, was especially influenced by

2 For an overview of this controversy, started with Robinson (1953), see Bliss et al. (2005) and Harcourt (1969; 1972). 
Ricardo-although as Pratten (1999) notes, authors such as Garegnani prefer to see Sraffa's work as a revival of classical thought in general. Sen (1999) notes how his perspective is inspired by Smith, but is often unsympathetic toward Malthus, and was never an enthusiast of Ricardo's analytical framework. Other members of the Cambridge "welfare" tradition, such as Sidgwick and Marshall, are much influenced by Mill.

But these disagreements between authors of the Cambridge traditions are actually another similarity with classical economic thought, for they are a continuation of the discussions that took place between classical authors themselves-for example, the famous exchanges between Ricardo and Malthus. These exchanges were essential to the pluralism and the dialectic of classical economic thought, and continued to be fundamental to the atmosphere lived in Cambridge.

Furthermore, the grounding of the Cambridge tradition in classical economics also distinguishes it from other economic traditions. Effectively, central authors of the "old" institutional tradition such as Thorstein Veblen (1898) considered classical economics to be pre-Darwinian, naturalistic, and thus inadequate, and John Kenneth Galbraith (1958) argued that the existence of affluence, a phenomenon that classical economists (placed in a world characterized by scarcity) did not foresee, renders classical economics less adequate for the analysis of the contemporary world. The classical origins of the Cambridge tradition also distinguish it from Austrian economics, the roots of which can be found in the work of the marginalist Carl Menger.

The classical origins of the Cambridge tradition also explain its similarities with the Marxian tradition. In fact, Karl Marx was strongly influenced by classical economic thought, and authors such as Smith and Ricardo (Schumpeter, 1992, argues that Ricardo was the key influence), who inspired Cambridge economists such as Sen and Sraffa, respectively. Furthermore, like the Cambridge tradition, Marx also provided a conception where economics and philosophy are closely interconnected, and Marxian analysis is permeated by a strong social concern that, as we will see in the next section, is another central feature of the Cambridge tradition.

Moreover, Marx is often identified by Post Keynesians as one of the central inspirations of this tradition, and Sen notes that "I have got more joy out of reading Smith than anyone else," but he adds "Marx comes very close to it" (quoted by Klamer, 1989, p. 141). Effectively, Sen's initial work was greatly influenced not just by the Cambridge economists Sraffa, Robertson, and Robinson (and in India, by Amiya Dasgupta) but also by the Cambridge Marxist author Maurice Dobb. As Pratten (1999) noted, 
Garegnani also argued that Sraffa was bringing back a classical tradition that included Marx, whose work Sraffa (and Garegnani) considered to be in many respects one of the highest points of analytical development of classical thought.

Of course, there are also some differences between Marxian economics and the views of some authors of the Cambridge tradition. Keynes saw his own theory as a significant advance over Marx's-whose work he thought to be considerably dated - and many Marxist authors would not agree with Sen's (1999) perspective on the role of the market, which is grounded on an economic argument defending the economic efficiency of markets, and an ethical argument according to which the freedom of exchange provided by the market is morally valuable by itself. Sen's (ibid.) defense of the role of the market in development processes seems closer to the analysis of Austrian economists such as Friedrich Hayek, than to Marxian analysis, or at least the orthodox interpretation of the

latter. In any case, the relationship between the Cambridge tradition and Marxian economics surely deserves further elaboration.

\section{The social philosophy of the Cambridge tradition}

Another central theme uniting the Cambridge traditions is their social philosophy. Pasinetti (2005) noted that a strong social concern is one of the central features of the Cambridge school of Keynesian economics. This strong social concern also underpins the Cambridge "welfare" tradition (including Sen's capability approach), which has been much concerned with human well-being. Furthermore, this strong social concern comes combined with a similar social philosophy that underpins the contributions of many authors of the Cambridge traditions, such as Keynes and Sen.

One can argue that even though Sen does not provide a fully fledged theory of development, he does nevertheless provide the basic underpinnings for such a theory. The central presupposition for such a theory is that the redistribution of capabilities, freedom, and social welfare are not only ends to be achieved but also the means to promote well-being and advancement.

Sen (1999) noted how health and education sectors are relatively labor intensive. Because wages are lower in developing countries, sectors such as health and education have a cost structure in those countries that is relatively cheaper comparatively to that of developed countries, thus facilitating the implementation of social policies in developing countries. Furthermore, policies oriented to redistributive social goals concerning 
sectors such as education, health, or emancipation, by improving human capital and human capabilities, also foster economic growth and human development, releasing in turn more resources to be applied in promoting those social goals.

In this sense, for Sen, it is a fallacy to say that first there must be inequality and lower social achievement in order to achieve economic growth, and that only after an economic growth similar to that of developed countries is attained can one apply social policies. Developing countries require a lower level of economic growth than developed countries for the adoption of social policies (due to a cheaper cost structure), and the latter are essential to the formation of human capital, which is typically lower in developing countries.

Now, the principle behind this idea-that is, that social goals such as redistribution of capabilities are both an end and a means to development-is very close to the conclusion Keynes takes from his own theory. In fact, Keynes believed that his theory led to a radically different social philosophy, which is strikingly compatible with, and complementary to, what Sen advocates in his capability approach.

As noted by Thirlwall $(2002,2003)$, developing countries typically face a constraint in demand which undermines their economic growth. Keynes (1936) argued that when there is the need to expand demand, income distribution should favor those with less income, because those have a higher marginal propensity to consume, and thus favoring them will stimulate aggregate demand. So Keynes's theory provides an economic mechanism that again shows how social policy (in this case concerning income distribution) is both an end and a means for growth and development, in line with the perspective Sen came to advocate later. Keynes considers this principle to be fundamental to his social philosophy. Hence, there is a strong similarity between the social philosophy of the capability approach and that which Keynes argued was to follow from his own theory.

Furthermore, the capability approach and Post Keynesianism work at different levels of abstraction. Sen's capability approach has been mostly concerned with the nature of development, but without providing a theory of growth and development (see Martins, 2006, 2007a, 2007b). The Post Keynesian tradition, on the other hand, has made central contributions to growth theory (see, for example, Harrod, 1939, 1948; Kaldor, 1960, 1978) while addressing extensively issues such as growth and development (see, for example, Pasinetti, 1993; Thirlwall 2002, 2003), but lacks a general conception of development processes. By working at different levels of abstraction, both perspectives can be 
seen as complementary and mutually enriching in the study of development processes.

Of course, the question arises as to whether there is any other common ground that justifies joining Sen's capability approach and Post Keynesianism together, other than geographical origin, historical pedigree (and their classical roots), a similar social philosophy, and the existence of complementarities between both approaches. I will now argue that the ontological and methodological underpinnings of the Cambridge traditions also reveal many common features.

\section{Ontology and the Cambridge traditions}

Another similarity between the capability approach and Post Keynesian economics springs from their ontological underpinnings. It has been suggested that the coherence of the Post Keynesian project ultimately lies at an ontological level, and not at the level of substantive theory. ${ }^{3}$

In fact, Lawson (2006) argued that although mainstream economics is characterized by an insistence on the ubiquitous use of mathematicodeductive methods (which mainstream economists believe to be essential for economics to become a scientific discipline), the essence of heterodox approaches consists in being ontologically oriented (rather than being defined in terms of method as mainstream economics), with each heterodox tradition focusing on a specific theme.

Post Keynesian economists typically focus on uncertainty and historical processes, Austrian economists emphasize the intersubjective nature of knowledge and its impact on the market process, "old" institutional economists are mostly concerned with causes of change and causes of stability in economic processes (among which technology and institutions play a key role), and Marxian economists focus on the contradictions and dynamics of the capitalist process.

But the distinguishing feature of each heterodox tradition, such as Post Keynesianism, Austrian economics, institutional economics, and Marxian economics, springs from an enduring concern with the ontological nature of each of the latter issues - that is, uncertainty, intersubjectivity, causes of stability and change, and the contradictions of the capitalist process, respectively, rather than the particular substantive theories each tradition uses when studying these issues.

3 See Lawson (1994, 1999, 2003). For a discussion on the coherence of Post Keynesianism, see also Arestis (1996), Dow (1992), Hamouda and Harcourt (1988), and Sawyer (1988). 
Within the spirit of Lawson's (ibid.) proposal for distinguishing heterodox traditions in terms of the ontological aspects of reality they focus on, we can find that a key feature of the Cambridge tradition seems to be its emphasis on the open nature of the social realm. That is, due to the existence of fundamental uncertainty, strict, even regularities of the form "if event $X$ then event $Y$ " are not ubiquitous in the social realm, as would be the case in a closed system (see also Lawson, 2003, for elaborations).

Uncertainty plays a key role in the writings of Keynes, and in the Post Keynesian tradition. ${ }^{4}$ This ontological aspect was, of course, further elaborated outside Cambridge by authors working within Post Keynesianism - an example is the idea of nonergodic processes developed by American Post Keynesians such as Paul Davidson (1994).

The role of uncertainty, and the open nature of the social realm, is also important to the Cambridge "welfare" tradition. The open nature of the social realm is noted by Marshall (1890) when he argued that economists should ground their analysis on biological dynamics, and not in equilibrium concepts inspired in physics, such as the ones that pervade contemporary neoclassical thinking (for elaborations, see Pratten, 1998).

One of the reasons the social realm is an open system is that human beings do not always follow laws of behavior like natural phenomena, and always have the possibility of choice - that is, any action could have been otherwise, as Lawson (1997) stressed. In fact, Sen (1982; 2002) argued that the different motivations, goals, values, and reasons for choice of human agents cannot all be described by the same preference ordering. It follows that one cannot assume a priori that actual behavior, which arises out of the joint effect of these competing motivations, will display regularities that can be described as choice driven by one preference ordering.

Effectively, for Sen, the multiple preference orderings that drive the human agent can be, and often are, incomplete, generating situations where there are options that are not ranked vis-à-vis each other in any way. Hence, in Sen's conception of the human agent, there will often exist what Post Keynesians term as "fundamental uncertainty" concerning which choice will be made (see Martins, 2006, for elaborations). So Sen's conception of the human agent entails that social reality constitutes an open system.

4 This was noted by Arestis et al. (1999), Davidson (1994), Harcourt (2003), Lawson (1993; 1994; 1999; 2003), Pasinetti (2005), and Runde (1990; 1991; 1994a; 1994b). 
Another reason social reality is an open system is the existence of internal relations. According to Lawson:

the social realm is ... highly internally related. Aspects or items are said to be internally related when they are what they are, or can do what they do, by virtue of the relations in which they stand. (2003, p. 17)

This ontological conception of reality is considered by Lawson (ibid.) to be one of the central characteristics of Post Keynesian economics, and as Harcourt (2003) and Lawson (2003) noted, is present in the writings of Keynes, who distinguishes between the cases when the whole is, and when the whole is not, reducible to its constituent parts:

if different wholes were subject to laws qua wholes and not simply on account of and in proportion to the difference of their parts, knowledge of a part could not lead, it would seem, even to presumptive or probable knowledge as to its association with other parts. Given, on the other hand, a number of legally atomic units and the laws connecting them, it would be possible to deduce their effects pro tanto without an exhaustive knowledge of all the coexisting circumstances. (Keynes, 1973, pp. 277-278)

As Harcourt (2003) noted, Keynes is especially concerned with the cases when the whole is more than the sum of the parts, due to the interconnectedness of social phenomena.

Sraffa's (1926) critique of neoclassical economics, and the alternative system he provided (Sraffa, 1960) also stress the interconnectedness of the various parts of the economic system. In fact, Sraffa's (1926) critique of marginal theory highlights the fact that a given market cannot be analyzed as if it were isolated from other markets, because the various parts of the economic system are closely interconnected.

It is important to note that although most Post Keynesians have followed Keynes closely in taking into account both fundamental uncertainty and the interconnectedness of the economic system, Sraffa and his followers have emphasized mostly the interconnectedness of the economic system, rather than the role of fundamental uncertainty.

Furthermore, as Pratten (1999) noted, in their economic theory, Sraffians use the methodological assumption of closure as a first step, in order to then address the complexity of the economic system, which is nevertheless taken to be an open and interconnected system. Of course, the relationship between Sraffians and other Post Keynesians deserves further elaboration, as noted above.

The capability approach also acknowledges the interconnectedness of social processes. In fact, Sen argued that the study of development has to 
take into account the complex interconnections between (instrumental) freedoms that include "political freedoms," "economic facilities," "social opportunities," "transparency guarantees," and "protective security" (1999, p. 38). For Sen, such interconnections are essential features of reality. As Sen argued, "[T] he capability perspective involves, to some extent, a return to an integrated approach to economic and social development championed particularly by Adam Smith" (ibid., p. 294).

The interconnectedness of social processes, which implies that the part cannot be taken for the whole, is thus another common feature of the Cambridge traditions, present in the Post Keynesian emphasis on macroeconomics before microeconomics (on which see Harcourt, 2003, and Pasinetti, 2005), and in Sen's (1999) insistence on analyzing development processes in a multidimensional perspective.

\section{Methodology and language in the Cambridge tradition}

The existence of multiple debates within the Cambridge traditions, which parallels the exchanges of classical economists in many ways, points toward another central characteristic of the Cambridge traditions: the existence of multiple methods and languages. In fact, one would not expect anything else from a perspective characterized by exchanges and debates and concerned with the analysis of complex phenomena where uncertainty, openness, and interconnectedness are fundamental properties.

These methods and languages range from detailed statistical analyses to philosophical argument, present both in the Keynesian tradition and the Cambridge "welfare" tradition, from Sidgwick to Sen. The use of a plurality of methods underpins the Post Keynesian emphasis on the use of multiple languages (see Dow, 2005; Harcourt, 2003) but need not entail loss of internal consistency, which, as Pasinetti (2005) noted, is essential to the Cambridge Keynesian tradition but is not to be confused with formalism.

It also underpins the writings on the capability approach, which resorts to philosophical argument on one hand, and to statistical analysis and measurement techniques on the other hand. The concept of "rich description" used by Cambridge economist Dobb, who was a key influence for Sen (Klamer, 1989), also captures this concern with a pluralist language (for elaborations, see Sen, 2005; Walsh, 2000, 2003, 2008).

Pratten $(2004 a, 2004 b)$ argued that an opposition toward uncritical mathematical formalization as the only language or method to be used is a key characteristic of the Cambridge economic tradition. Weintraub 
(2004) seems to suggest that the opposition toward mathematical formulation springs from the inability of many Cambridge economists to follow the developments in mathematics, and gives Marshall, Keynes, and Robinson as examples.

It can be argued, however, that the opposition to an exclusive use of mathematical methods springs from the difficulties that arise when analyzing an ontologically complex process with such methods. The phenomena in which Cambridge economists are interested are characterized by openness, interconnectedness, and uncertainty, and such type of phenomena can rarely (if ever) be completely understood using a single method, such as mathematico-deductive methods. Such being the case, it is only natural that a pluralist approach to methodology emerges.

In fact, to use mathematico-deductive methods in conditions under which they are not appropriate reveals more mathematical incompetence than recognizing their inadequateness under such conditions. Mathematical competence entails not just the ability to engage in deductive reasoning, but also (and perhaps especially) the capability for abductive reasoning (for placing ourselves outside of the deductivist structure of a given mathematical problem, and questioning the very axioms posited in such a deductivist structure), which includes the capability to assess the conditions under which deductivist methods are appropriate. Thus, competent mathematicians such as Sen, and many others in the Cambridge tradition, recognize that mathematics is not a unique foundation for economics, because the complex reality that economic analysis deals with requires a plurality of methods (see Lawson, 2001).

In fact, a realist emphasis is another defining feature of the methodology of the Cambridge tradition, which is present both in Post Keynesianism (see Lawson, 1994, 1999, 2003; Pasinetti, 2005) and in the Aristotelian roots of the capability approach (see Martins, 2007a, 2007b; Nussbaum, 1992, 2000, 2003; Sen, 1999, p. 289). It can even be argued that the methodological presuppositions of the Cambridge tradition are consistent with a critical realist ontology.

Critical realism in economics is a perspective on social ontology that has been systematized in Lawson (1997, 2003). Lawson (1999, 2003) argued that the methodological and ontological tenets of critical realism and Post Keynesianism are compatible, and that the coherence of Post Keynesianism ultimately lies in the adoption of a critical realist ontology (on this topic, see also Lewis and Runde, 1999). The connections between critical realism and authors of the Cambridge "welfare" tradition such as Marshall have been elaborated by Pratten (1998), and the 
similarities between critical realism and Sen's capability approach were also discussed in Martins (2006, 2007b).

This realist approach constitutes thus another similarity between the projects of the Cambridge economic tradition. In fact, if methodological pluralism, which springs from an ontological concern with openness and interconnectedness, is a key characteristic of the Cambridge tradition, it is only natural that critical realism in economics, itself a project concerned with methodological pluralism, and explicitly ontologically oriented toward the study of categories such as openness or interconnectedness, has emerged recently in Cambridge, too (for elaborations, see Bigo, 2006; Pratten, 2004a, 2004b).

\section{Concluding remarks}

Sen's capability approach provides an analysis of the nature of development but does not give us a substantive theory that explains development processes. It was argued that Post Keynesian economics can be fruitfully combined with the capability approach to that effect. Because the capability approach and Post Keynesianism work at different levels of abstraction, they can be complementary and mutually enriching. This would also imply some interaction between the two Cambridge economic traditions - that is, the Cambridge "welfare" tradition and the Cambridge "Keynesian" tradition.

In fact, both the capability approach and Post Keynesian economics seem to be part of what may be called the Cambridge economic tradition. This tradition can be characterized by an inspiration in classical economics, a similar social philosophy, according to which the ends to human well-being (such as income redistribution or the expansion of human capabilities) are the means to it too, a realist perspective, and a focus on ontological themes such as openness, uncertainty, and interconnectedness. These topics cannot be addressed without the use of a plurality of methods and languages and naturally lead to the existence of not only plural methods and languages but also ongoing debates and exchanges, which are part of a continuous dialectic.

\section{REFERENCES}

Arestis, P. "Post-Keynesian Economics: Towards Coherence, Critical Survey." Cambridge Journal of Economics, 1996, 20 (1), 111-135.

Arestis, P.; Dunn, S.; and Sawyer, M. "Post Keynesian Economics and Its Critics." Journal of Post Keynesian Economics, Summer 1999, 21 (4), 527-549. 
Backhouse, R.E. "Sidgwick, Marshall and the Cambridge School of Economics." History of Political Economy, 2006, 38 (1), 15-44.

Bigo, V. "Open and Closed Systems and the Cambridge School." Review of Social Economy, 2006, 64 (4), 493-514.

Bliss, C.; Cohen, A.J.; and Harcourt, G.C. Capital Theory. Cheltenham, UK: Edward Elgar, 2005.

Davidson, P. Post Keynesian Macroeconomic Theory: A Foundation for Successful Economic Policies for the Twenty-First Century. Aldershot, UK: Edward Elgar, 1994. "Setting the Record Straight on A History of Post Keynesian Economics." Journal of Post Keynesian Economics, Winter 2003-4, 26 (2), 245-272.

. "Responses to Lavoie, King, and Dow on What Post Keynesianism Is and Who Is a Post Keynesian.” Journal of Post Keynesian Economics, Spring 2005, 27 (3), 393-408.

Dequech, D. "Neoclassical, Mainstream, Orthodox, and Heterodox Economics." Journal of Post Keynesian Economics, Winter 2007-8, 30 (2), 279-302.

Dow, S. "Post Keynesian School." In D. Mair and A. Miller (eds.), A Modern Guide to Economic Thought: An Introduction to Comparative Schools of Thought in Economics. Aldershot, UK: Edward Elgar, 1992, pp. 176-206.

_. "Axioms and Babylonian Thought: A Reply." Journal of Post Keynesian Economics, Spring 2005, 27 (3), 385-391.

Galbraith, J.K. The Affluent Society. New York: Houghton Mifflin, 1958.

Garegnani, P. "Value and Distribution in the Classical Economists and Marx." Oxford Economic Papers, 1984, 36 (2), 291-325.

. "Misunderstanding Classical Economics? A Reply to Blaug." History of Political Economy, 2002, 34 (1), 241-254.

Hamouda, O.F., and Harcourt, G.C. "Post Keynesianism: From Criticism to Coherence." Bulletin of Economic Research, 1988, 40 (1), 1-33.

Harcourt, G.C. "Some Cambridge Controversies in the Theory of Capital." Journal of Economic Literature, 1969, 7 (2), 369-405.

. Some Cambridge Controversies in the Theory of Capital. Cambridge: Cambridge University Press, 1972.

. "Marshall, Sraffa, and Keynes: Incompatible Bedfellows?" In C. Sardoni (ed.), On Political Economists and Modern Political Economy: Selected Essays of G.C. Harcourt. London: Routledge, 1981, pp. 250-264.

"The Cambridge Economic Tradition.” In J. King (ed.), The Elgar Companion to Post Keynesian Economics. Cheltenham, UK: Edward Elgar, 2003, pp. 44-51. Harcourt, G.C., and Kerr, P. "Keynes and the Cambridge School." In W.J. Samuels, J.E. Biddle, and J.B. Davis (eds.), A Companion to the History of Economic Thought. Malden, MA: Blackwell, 2003, pp. 343-359.

Harrod, R. “An Essay in Dynamic Theory.” Economic Journal, March 1939, 40, 14-33.

—. Towards a Dynamic Economics. London: Macmillan, 1948.

Kaldor, N. Essays in Value and Distribution. London: Duckworth, 1960.

- Further Essays on Applied Economics. London: Duckworth, 1978.

Keynes, J.M. The Collected Writings of John Maynard Keynes, Vol. VIII: A Treatise on Probability. London: Macmillan, 1973. [Originally published in 1921.]

- The General Theory of Employment, Interest and Money. London, Macmillan, 1936.

King, J.E. A History of Post Keynesian Economics Since 1936. Aldershot, UK: Edward Elgar, 2002. 
. "Unwarping the Record: A Reply to Paul Davidson." Journal of Post Keynesian Economics, Spring 2005, 27 (3), 377-384.

Klamer, A. "A Conversation with Amartya Sen." Journal of Economic Perspectives, 1989, 3 (1), 135-150.

Lavoie, M. "Changing Definitions: A Comment on Davidson's Critique of King's History of Post Keynesianism." Journal of Post Keynesian Economics, Spring 2005, 27 (3), 371-376.

Lawson, T. "Keynes and Conventions.” Review of Social Economy, 1993, 51 (2), 174-201.

. "The Nature of Post Keynesianism and Its Links to Other Traditions: A Realist Perspective." Journal of Post Keynesian Economics, Summer 1994, 16 (4), 503-538.

. Economics and Reality. London: Routledge, 1997.

. "Connections and Distinctions: Post Keynesianism and Critical Realism." Journal of Post Keynesian Economics, Fall 1999, 22 (1), 3-14.

. "Back to Reality." Post-Autistic Economics Newsletter, May 2001, 6 (available at www.btinternet.com/ pae_news/review/issue6.htm).

Reorienting Economics. London: Routledge, 2003.

"The Nature of Heterodox Economics." Cambridge Journal of Economics, 2006, 30 (4), 483-505.

Lewis, P.A., and Runde, J. "A Critical Realist Perspective on Paul Davidson's Methodological Writings on-and Rhetorical Strategy for-Post Keynesian Economics." Journal of Post Keynesian Economics, Fall 1999, 22 (1), 35-56.

Marshall, A. Principles of Economics. London: Macmillan, 1890.

Martins, N. "Capabilities as Causal Powers." Cambridge Journal of Economics, 2006, $30(5), 671-685$. (1), 37-53.

"Ethics, Ontology and Capabilities." Review of Political Economy, 2007a, 19

. "Realism, Universalism and Capabilities." Review of Social Economy, 2007b, 65 (3), 253-278.

Medema, S. "The Hesitant Hand: Mill, Sidgwick, and the Evolution of the Theory of Market Failure." History of Political Economy, 2007, 39 (3), 331-358.

Nussbaum, M.C. "Human Functioning and Social Justice: In Defense of Aristotelian Essentialism." Political Theory, 1992, 20 (2), 202-246.

. Women and Human Development: The Capabilities Approach. Cambridge: Cambridge University Press, 2000.

_. "Capabilities as Fundamental Entitlements: Sen and Social Justice." Feminist Economics, 2003, 9 (2-3), 33-60.

Pasinetti, L.L. Structural Economic Dynamics. A Theory of the Economic Consequences of Human Learning. Cambridge: Cambridge University Press, 1993.

- "The Cambridge School of Keynesian Economics." Cambridge Journal of Economics, 2005, 29 (6), 837-848.

Pratten, S. "Marshall on Tendencies, Equilibrium and the Statical Method." History of Political Economy, 1998, 30 (1), 121-163.

. "The 'Closure' Assumption as a First Step: Neo-Ricardian Economics and Post-Keynesianism.” In S. Fleetwood (ed.), Critical Realism in Economics: Development and Debate. London: Routledge, 1999, pp. 21-41.

. "Mathematical Formalism in Economics: Consequences and Alternatives." Economic Affairs, 2004a, 24 (2), 37-42. 
(3), 50-52

"Reclaiming History: A Reply to Weintraub.” Economic Affairs, 2004b, 24

Putnam, H. The Collapse of the Fact/Value Dichotomy and Other Essays. Cambridge: Harvard University Press, 2002.

Robinson, J. "The Production Function and the Theory of Capital." Review of Economic Studies, 1953, 21 (2), 81-106.

Runde, J. "Keynesian Uncertainty and the Weight of Arguments." Economics and Philosophy, 1990, 6 (2), 275-292.

_. "Keynesian Uncertainty and the Instability of Beliefs." Review of Political Economy, 1991, 3 (2), 125-145.

. "Keynes After Ramsey: In Defence of 'A Treatise on Probability." Studies in History and Philosophy of Science, 1994a, 25 (1), 97-121.

- "Keynesian Uncertainty and Liquidity Preference." Cambridge Journal of Economics, 1994b, 18 (2), 129-144.

Sawyer, M. (ed.). Post-Keynesian Economics. Aldershot, UK: Edward Elgar, 1988.

Schumpeter, J. Capitalism, Socialism and Democracy. London: Routledge, 1992.

[Originally published in 1942.]

Sen, A. Choice, Welfare and Measurement. Oxford: Basil Blackwell, 1982.

—. Commodities and Capabilities. Oxford: Oxford University Press, 1985.

- Development as Freedom. Oxford: Oxford University Press, 1999.

Rationality and Freedom. Cambridge, MA: Belknap Press, 2002.

"Sraffa, Wittgenstein, and Gramsci." Journal of Economic Literature, 2003, 41 (4), 1240-1255. 107-113

"Walsh on Sen After Putnam." Review of Political Economy, 2005, 17 (1),

Sraffa, P. "The Laws of Returns Under Competitive Conditions." Economic Journal, 1926, 36 (144), 535-550.

- Production of Commodities by Means of Commodities: Prelude to a Critique of Economic Theory. Cambridge: Cambridge University Press, 1960.

Thirlwall, A.P. The Nature of Economic Growth: An Alternative Framework for Understanding the Performance of Nations. Cheltenham, UK: Edward Elgar, 2002.

- Growth and Development, 7th ed. London: Macmillan, 2003.

Veblen, T. "Why Is Economics Not an Evolutionary Science?" Quarterly Journal of Economics, 1898, 12 (4), 373-397.

Walsh, V. "Smith After Sen." Review of Political Economy, 2000, 12 (1), 5-25.

. "Sen After Putnam." Review of Political Economy, 2003, 15 (3), 315-394.

"Freedom, Value and Sen: Towards a Morally Enriched Classical Economic Theory." Review of Political Economy, 2008, 20 (2), 199-232.

Weintraub, E.R. "Making Up History: A Comment on Pratten.” Economic Affairs, 2004, 24 (3), 46-49. 